Prepared in cooperation with the National Park Service

\title{
Preliminary Hydrogeologic Assessment near Tassi and Pakoon Springs, Western Part of Grand Canyon-Parashant National Monument, Arizona
}

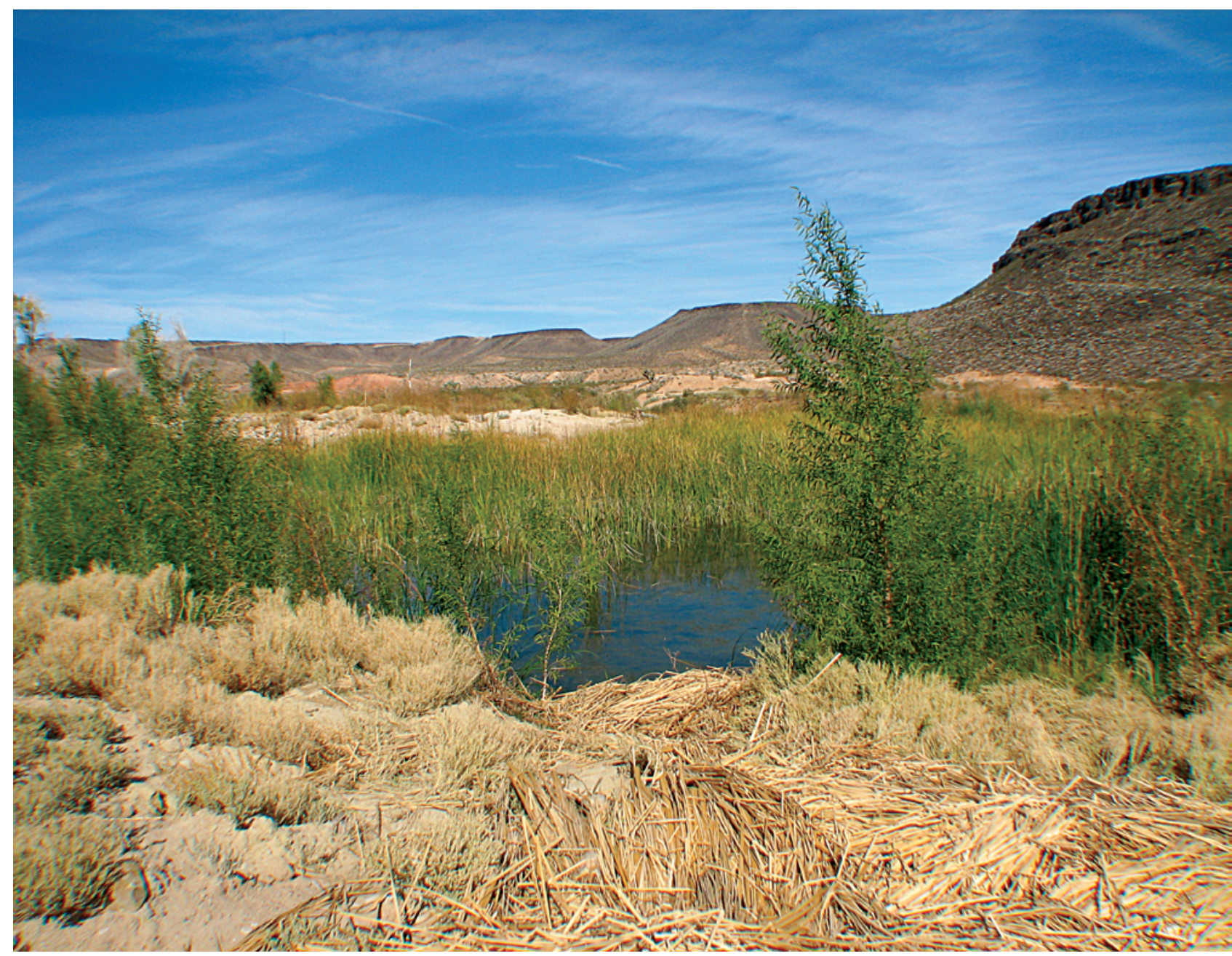

Scientific Investigations Report 2012-5276 
Prepared in cooperation with the National Park Service

\section{Preliminary Hydrogeologic Assessment near Tassi and Pakoon Springs, Western Part of Grand Canyon-Parashant National Monument, Arizona}

By Margot Truini

Scientific Investigations Report 2012-5276 


\section{U.S. Department of the Interior \\ KEN SALAZAR, Secretary}

\section{U.S. Geological Survey Marcia K. McNutt, Director}

\section{U.S. Geological Survey, Reston, Virginia 2013}

For more information on the USGS - the Federal source for science about the Earth, its natural and living resources, natural hazards, and the environment, visit http://www.usgs.gov or call 1-888-ASK-USGS

For an overview of USGS information products, including maps, imagery, and publications, visit http://www.usgs.gov/pubprod

Suggested citation:

Truini, M., 2013, Preliminary hydrogeologic assessment near Tassi and Pakoon Springs, western part of Grand Canyon-Parashant National Monument, Arizona: U.S. Geological Survey Scientific Investigations Report 2012-5276, 12 p.

Any use of trade, product, or firm names is for descriptive purposes only and does not imply endorsement by the U.S. Government. 


\section{Contents}

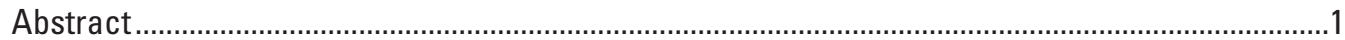

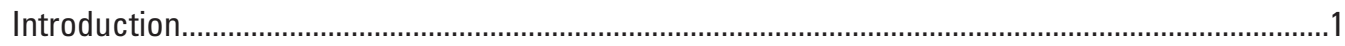

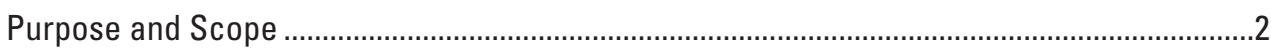

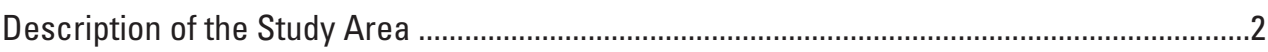

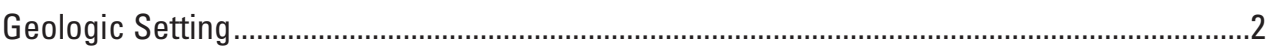

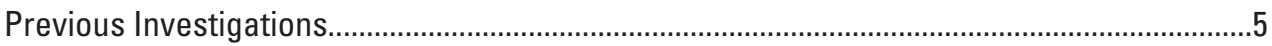

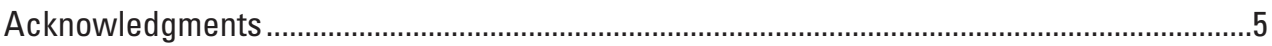

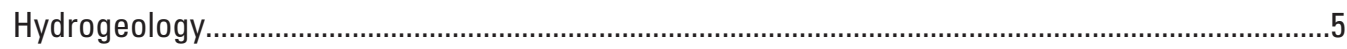

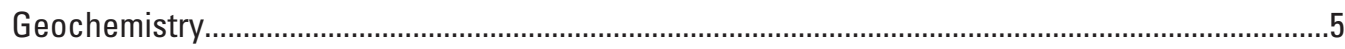

Summary

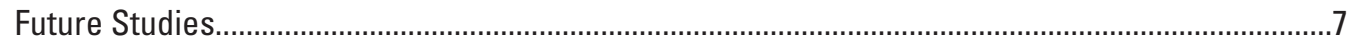

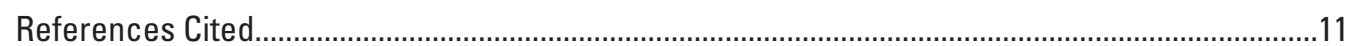

\section{Figures}

1. Grand Canyon-Parashant National Monument, northwestern Arizona, showing location

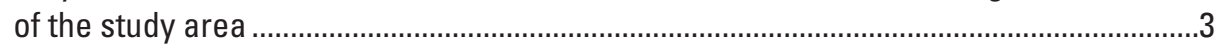

2. Map showing generalized geology in Grand Canyon-Parashant National Monument,

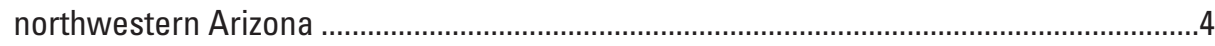

3. Water-level contours and general direction of groundwater movement, Grand CanyonParashant National Monument, northwestern Arizona ....................................................6

4. Grand Canyon-Parashant National Monument, northwestern Arizona, showing water chemistry and distribution of dissolved solids in the groundwater from springs.............9

5. Signatures of oxygen and hydrogen isotopes in water from selected springs in the Arizona Strip $(A)$ and selected springs in Grand Canyon-Parashant National Monument, northwestern Arizona $(B)$. Stable isotopic data are from the Grand Canyon Wildlands Council, Inc. (2002)

\section{Tables}

1. Water levels and aquifer geology for wells in the western part of Grand Canyon-Parashant National Monument, northwestern Arizona.....................................................................7

2. Major-ion and stable-isotope chemistry from springs in the western Grand Canyon-Parashant National Monument, northwestern Arizona. 


\section{Conversion Factors}

Inch/Pound to SI

\begin{tabular}{lcl}
\hline Multiply & By & To obtain \\
\hline & Length & \\
\hline inch (in.) & 2.54 & centimeter $(\mathrm{cm})$ \\
\hline inch (in.) & 25.4 & millimeter $(\mathrm{mm})$ \\
\hline foot (ft) & 0.3048 & meter $(\mathrm{m})$ \\
\hline mile (mi) & 1.609 & kilometer $(\mathrm{km})$ \\
\hline & Volume & \\
\hline gallon (gal) & 3.785 & liter $(\mathrm{L})$ \\
\hline gallon (gal) & 0.003785 & cubic meter $\left(\mathrm{m}^{3}\right)$ \\
\hline gallon (gal) & 3.785 & cubic decimeter $\left(\mathrm{dm}^{3}\right)$ \\
\hline & Flow rate & \\
\hline gallon per minute (gal/min) & 0.06309 & liter per second $(\mathrm{L} / \mathrm{s})$ \\
\hline
\end{tabular}

Temperature in degrees Celsius $\left({ }^{\circ} \mathrm{C}\right)$ may be converted to degrees Fahrenheit $\left({ }^{\circ} \mathrm{F}\right)$ as follows:

${ }^{\circ} \mathrm{F}=\left(1.8 \times{ }^{\circ} \mathrm{C}\right)+32$

Temperature in degrees Fahrenheit $\left({ }^{\circ} \mathrm{F}\right)$ may be converted to degrees Celsius $\left({ }^{\circ} \mathrm{C}\right)$ as follows:

${ }^{\circ} \mathrm{C}=\left({ }^{\circ} \mathrm{F}-32\right) / 1.8$

Altitude, as used in this report, refers to distance above the vertical datum.

Specific conductance is given in microsiemens per centimeter at 25 degrees Celsius $(\mu \mathrm{S} / \mathrm{cm}$ at $\left.25^{\circ} \mathrm{C}\right)$.

Concentrations of chemical constituents in water are given either in milligrams per liter (mg/L) or micrograms per liter $(\mu \mathrm{g} / \mathrm{L})$. 


\title{
Preliminary Hydrologic Assessment near Tassi and Pakoon Springs, Western Part of Grand Canyon-Parashant National Monument, Arizona
}

\author{
By Margot Truini
}

\section{Abstract}

Tassi and Pakoon Springs are both in the Grand Wash Trough in the western part of Grand Canyon-Parashant National Monument on the Arizona Strip. The monument is jointly managed by the National Park Service (NPS) and the Bureau of Land Management. This study was in response to NPS's need to better understand the influence from regional increases in groundwater withdrawals near Grand CanyonParashant on the groundwater discharge from Tassi and Pakoon Springs.

The climate of the Arizona Strip is generally semiarid to arid, and springs in the monument provide the water for the fragile ecosystems that are commonly separated by large areas of dry washes in canyons with pinyon and juniper. Available hydrogeologic data from previous investigations included water levels from the few existing wells, location information for springs, water chemistry from springs, and geologic maps. Available groundwater-elevation data from the wells and springs in the monument indicate that groundwater in the Grand Wash Trough is moving from north to south, discharging to springs and into the Colorado River. Groundwater may also be moving from east to west from Paleozoic rocks in the Grand Wash Cliffs into sedimentary deposits in the Grand Wash Trough. Finally, groundwater may be moving from the northwest in the Mesoproterozoic crystalline rocks of the Virgin Mountains into the northern part of the Grand Wash Trough.

Water discharging from Tassi and Pakoon Springs has a major-ion chemistry similar to that of other springs in the western part of Grand Canyon-Parashant. Stable-isotopic signatures for oxygen-18 and hydrogen-2 are depleted in the water from both Tassi and Pakoon Springs in comparison to other springs on the Arizona Strip. Tassi Spring discharges from multiple seeps along the Wheeler Fault, and the depleted isotopic signatures suggest that water may be flowing from multiple places into Lake Mead and seems to have a higher elevation or an older climate source. Elevated water temperatures and a depleted stable-isotopic signature for Pakoon Springs suggest that the water may be traveling along a deep circulating flowpath, have multiple sources of water, been recharged at a high elevation, and (or) has an older climate source.

\section{Introduction}

Tassi and Pakoon Springs are both in the western part of Grand Canyon-Parashant National Monument, near the Arizona-Nevada State line on the Arizona Strip (fig. 1). The monument is jointly managed by the National Park Service (NPS) and the Bureau of Land Management (BLM). Tassi Spring, which is situated within the NPS parcel, and was developed as part of an original ranch homestead where the water from the spring was used for domestic and irrigation purposes. The cultural landscape and historic structures near Tassi Spring are currently being managed in part by Grand Canyon-Parashant National Monument and the Lake Mead National Recreation Area's Cultural Resources Branch. Pakoon Springs, which was privately owned, was obtained by the BLM when the area became part of a national monument in November 2002 (Kathleen Harcksen, written commun., 2011). The NPS and BLM have been concerned for some time that increasing groundwater development near the communities of Mesquite, Nev., and St. George, Utah, could potentially affect the quantity and quality of groundwater discharging from Tassi and Pakoon Springs. To address this concern the NPS requested that the U.S. Geological Survey (USGS) conduct a technical evaluation of existing water-quality/chemical data, hydrologic data, and geologic maps to identify any gaps that would hinder defining the regional hydrogeology in relation to the flows at Tassi and Pakoon Springs.

Tassi Spring is situated near an old ranch house on a bench where the water flows into an irrigation ditch, once delivered to pastures for cattle grazing but today moving through a breach in the levee where it enters Pigeon Wash downstream of the ranch house. Seeps below the main spring once serviced a cistern that was used to provide water to the house and corral, whereas other seep waters had been diverted away from the ranch buildings by a French drain system. Tassi Spring supports the rare endemic Grand Wash Spring snail, 
a candidate for Federal listing, and the riparian area provides habitat for a diverse bird population and a protective haven for local mammals in the Mojave Desert (Charles Drost, oral commun., 2010).

Pakoon Springs can potentially provide an oasis of high biologic diversity and productivity in the surrounding landscape of the arid desert. Pakoon Springs Ranch was a working ranch for nearly a century, including cattle ranching, alfalfa production, and ostrich farming. The springs were dug and developed into six manmade ponds to store water for domestic use and to irrigate agricultural fields. The springs, riparian areas, and agricultural fields had been overrun by nonnative, invasive floral and faunal species. From approximately 2002 to 2011, the BLM, with help from Grand Canyon Wildlands Council, Inc., and others, removed all the structures and restored the landscape to approximate conditions that likely existed before the establishment of the ranch (Kathleen Harcksen, oral commun., 2011).

\section{Purpose and Scope}

The purpose of this report is to provide an initial technical assessment of existing hydrologic, geologic, and geochemical data in the western part of Grand Canyon-Parashant National Monument in order to better understand the relation between the regional groundwater system and Tassi and Pakoon Springs. The assessment will determine gaps in the data needed to fully comprehend the effects of groundwater pumping by local communities on spring flows in Grand CanyonParashant National Monument.

The scope of this study involved a preliminary analysis of existing spring discharge, groundwater level, water-chemical, and geologic data. This report examines existing hydrologic, geologic, and water-chemical data and provides a limited interpretation of the regional hydrogeology in relation to Tassi and Pakoon Springs as well as to other springs in the Grand Wash Trough in the western part of Grand Canyon-Parashant National Monument. Spring discharge and groundwater-level data were obtained from the USGS Groundwater Site Inventory (GWSI), water-chemical data were provided by the Grand Canyon Wildlands Council, Inc. (2002), and geologic data were gleaned from completed mapping projects (Bohannon and others, 1993; Billingsley and Workman, 2000; Billingsley and Wellmeyer, 2003; Billingsley and others, 2004; Felger and Beard, 2010; Langenheim and others, 2010).

\section{Description of the Study Area}

Grand Canyon-Parashant National Monument, which was created by Executive order of President Clinton in 2000, is on the western side of the Arizona Strip (fig. 1). The monument is bounded on the west by the Arizona-Nevada State line, on the south-southwest by Grand Canyon National Park, on the northwest by the Virgin Mountains, and on the north and northeast by the Shivwits and Uinkaret Plateaus (fig. 1).
The monument is more than 1 million acres in area, including parts of the Shivwits and Uinkerat Plateaus, the entire Grand Wash Drainage, the Toroweap Valley, and the Mount Trumbull and Mount Logan Wilderness Areas. The NPS manages most of the southern areas adjacent to the Grand Canyon, and the BLM manages the remaining areas to the north including the Mount Trumbull and Mount Logan Wilderness Areas (fig. 1). The Arizona Game and Fish Department manages wildlife within the study area, and a few private inholdings also exist within the monument, particularly at the town of Mount Trumbull in Potato Valley (fig. 1).

Grand Canyon-Parashant National Monument is ecologically unique because the Sonoran, Great Basin, and Mojave Deserts all intersect in this region. The monument and the rest of the region provide critical habitat for several endangered or threatened species including the California condor, desert tortoise, willow flycatcher, bighorn sheep, endemic speckled dace, the Grand Wash Spring snail, pronghorn, and leopard frog. The fragile ecosystems supported by the springs are commonly separated by large areas consisting of dry washes in canyons with pinyon and juniper.

The climate of Grand Canyon-Parashant National Monument is generally semiarid to arid, with monthly averages for summertime and wintertime relatively close to climatologic data recorded at Pipe Spring National Monument (Western Regional Climate Center, http://www.wrcc. dri.edu/cgi-bin/cliF302010.pl?az6616, accessed December 10, 2012). Summertime average high temperatures at Pipe Spring National Monument range from 85 to $95^{\circ} \mathrm{F}$, and winter monthly average temperatures at range from 30 to $40{ }^{\circ} \mathrm{F}$. Total annual precipitation ranges from 5 inches (in) at the lowest elevations to 30 in at the highest elevations. Humidity is likewise extremely low in most environments but increases at higher elevations, and more than 90 percent of annual precipitation is estimated to be lost to evaporation and evapotranspiration (Iorns and others, 1965).

\section{Geologic Setting}

Grand Canyon-Parashant National Monument straddles the Colorado Plateau to the east and the Grand Wash Trough of the Basin and Range Province to the west. Pakoon and Tassi Springs are both within the Grand Wash Trough of the Basin and Range Province (fig. 2). The boundary between the Colorado Plateau and the Basin and Range Province follows the base of the lower Grand Wash Cliffs along the approximate position of the Grand Wash Fault (Billingsley and others, 2004).

The Grand Wash Trough is a 47 mile (mi) long depression, the north half of which comprises two major subbasins. The southern subbasin is a small 1- to 1.5-mi deep half-graben that lies west of the Wheeler Fault; the northern subbasin, which is more than $2.5 \mathrm{mi}$ deep, represents the deepest part of the Grand Wash Trough (fig. 2; Langenheim and others, 2010). The western margin of the Colorado Plateau consists of Paleozoic rocks that have been downfaulted and tilted westward toward the Grand Wash Trough. The west-dipping 


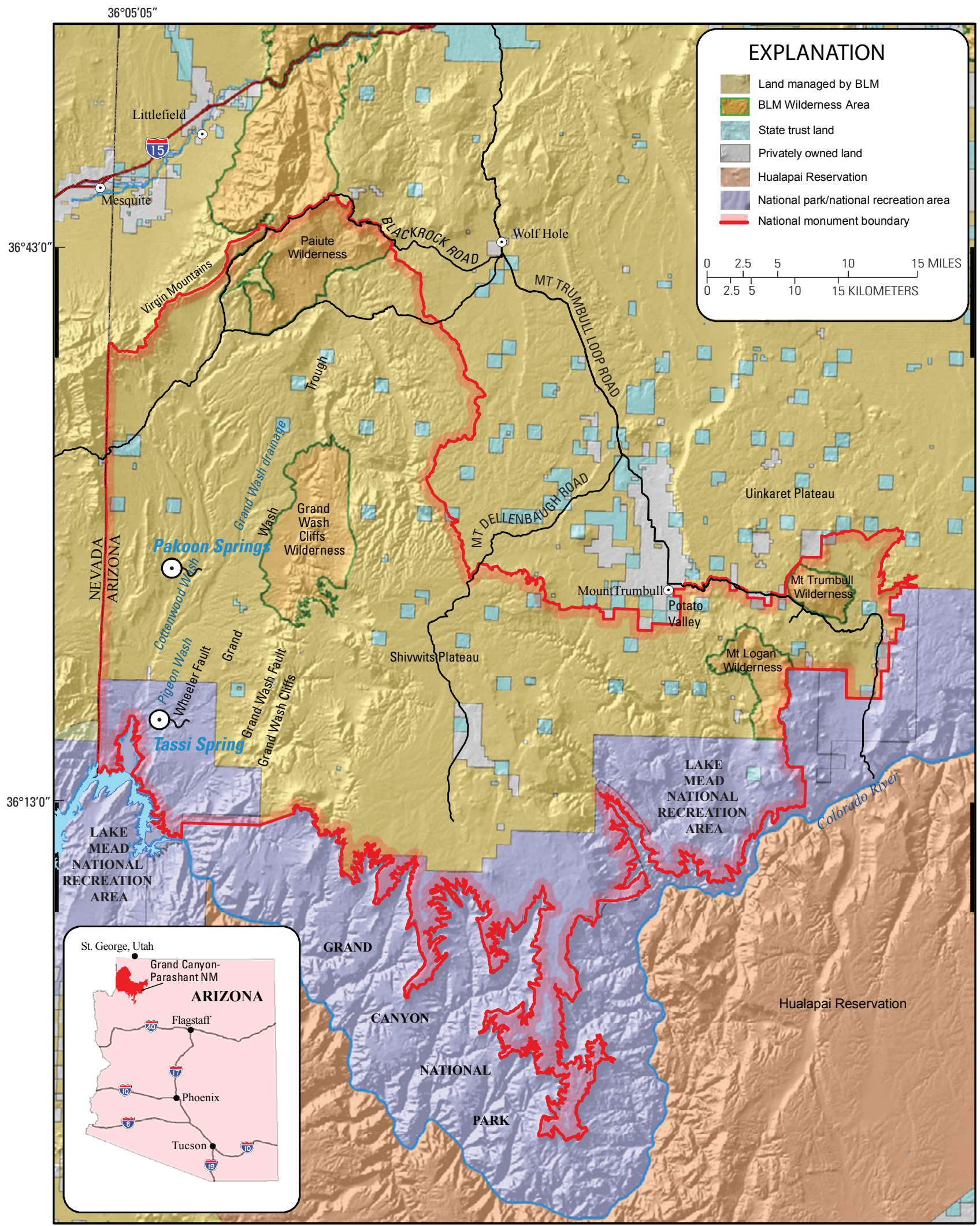

Figure 1. Grand Canyon-Parashant National Monument, northwestern Arizona, showing location of Tassi and Pakoon Springs. For fault locations, see fig. 2. Modified from Bureau of Land Management (BLM), 2012. 


\section{Preliminary Hydrologic Assessment near Tassi and Pakoon Springs, Western Part of Grand Canyon-Parashant National Monument}

strata may represent large blocks of Paleozoic rocks that have been tilted along the Grand Wash Fault by footwall drag. Most of these tilted Paleozoic rocks have been buried by Cenozoic sedimentary and volcanic deposits. The major faults include the Grand Wash Fault, along which the Paleozoic strata of Wheeler Ridge were downdropped to the west and tilted eastward, and the Wheeler Fault, which truncates Wheeler Ridge and drops Paleozoic strata down to the west in the subsurface (Billingsley and others, 2004).

Four Tertiary assemblages occupy the Grand Wash Trough and mostly bury the downdropped east-tilted fault blocks of Paleozoic and Mesozoic strata. (1) Earliest Cenozoic (24-18 Ma) sedimentary rocks consist of a lower redbrown conglomerate, a middle red siltstone and sandstone

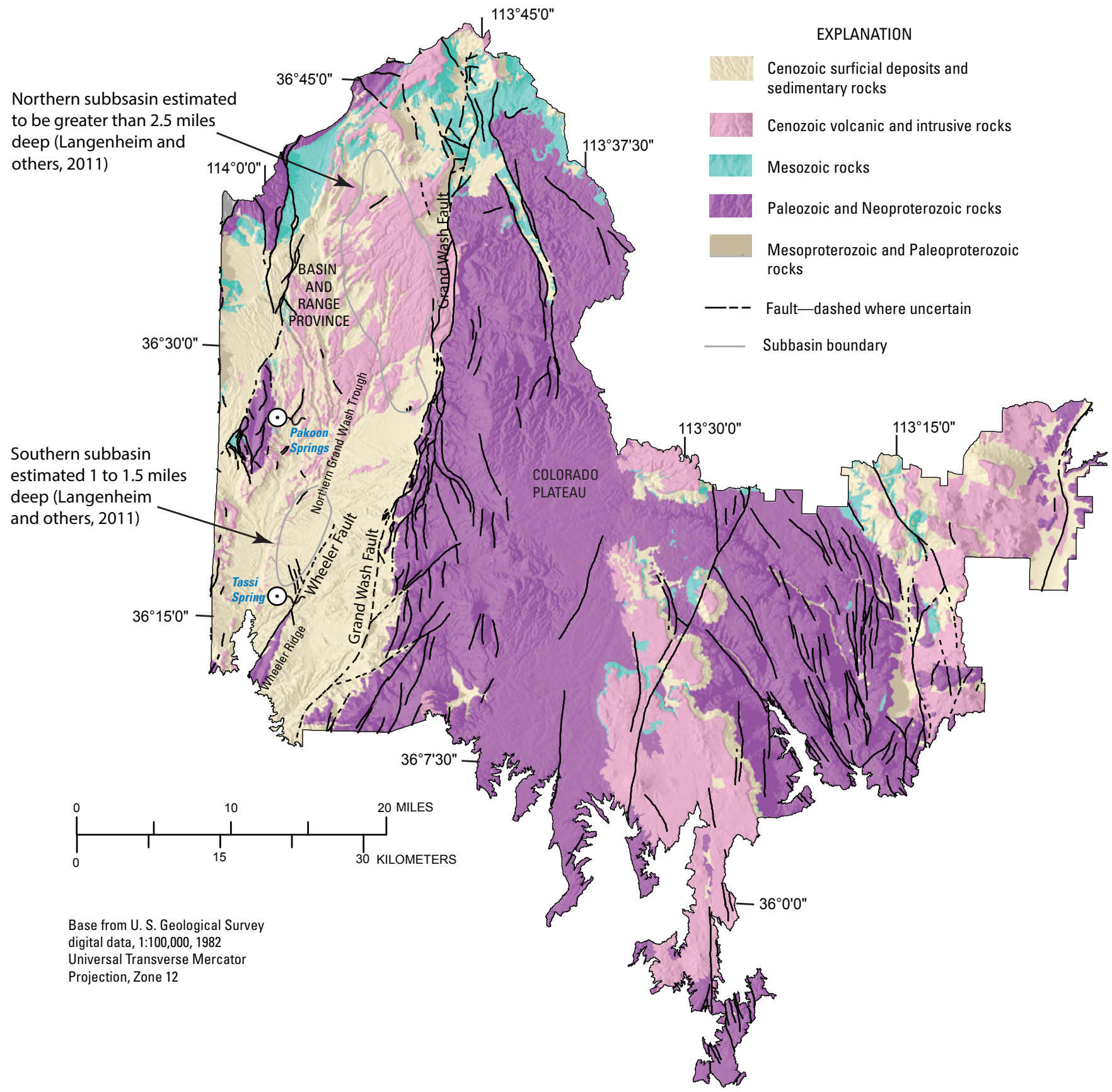

Figure 2. Generalized geologic map of Grand Canyon-Parashant National Monument, northwestern Arizona. Modified from Felger and Beard (2010). 
interbedded with gray silty limestone, and an upper limestone sequence (Bohannon, 1984). (2) The early Cenozoic sedimentary rocks are unconformably overlain by Tertiary rocks of the Grand Wash Trough and consist of fluvial and alluvial sedimentary deposits, freshwater-shallow-lake deposits, and shallow-basin evaporite deposits. (3) The deposits in the Grand Wash Trough are overlapped by the late Tertiary and Quaternary rocks of Grand Wash that crop out mostly west of the trace of the Wheeler Fault. These deposits consist of a basal conglomerate exposed along Grand Wash, overlain by red siltstone and sandstone of mostly fluvial and eolian origin. (4) Rocks of both the Grand Wash Trough and the Grand Wash are partly covered by extensive Pliocene basalt flows and interbedded fluvial gravel deposits between some of the flows. Early and late Tertiary alluvium and calcrete overlie the basalt flows (Billingsley and others, 2004).

Tertiary basalt flows in the Grand Wash Trough are associated with fissure eruptions and pyroclastic vents in the upper reaches of Grand Wash Trough to the north of Pakoon Springs, with some dikes along Cottonwood Wash southeast of Pakoon Springs. Most of the basalt along Grand Wash originated from sources to the north of the Grand CanyonParashant National Monument boundary and flowed southward down ancestral Grand Wash and Cottonwood Wash toward the Colorado River during late Pliocene time (Billingsley and others, 2004).

Tassi and Pakoon Springs, which are both to the west of the Grand Wash Fault within the Grand Wash Trough, discharge from the Cenozoic surficial deposits and sedimentary rocks that overlie the downfaulted east-dipping Paleozoic rocks. Pakoon Springs is to the east of the exposed east-dipping Paleozoic strata that form Pakoon Ridge, and Tassi Spring is on the west side of the exposed east-dipping Paleozoic strata along the Wheeler Fault (fig. 2; Billingsley and others, 2004).

\section{Previous Investigations}

Levings and Farrar (1979) completed a groundwater study that included limited spring inventory data. The Grand Canyon Wildlands Council (2002) inventoried 100 springs on the Arizona Strip between 1999 and 2002, including an allinclusive survey of the fauna and water conditions at each site.

Multiple studies conducted within riparian areas along the upper Colorado River corridor have shown that the perennial and intermittent springs, seeps, and natural ponds support riparian habitats which house endangered, endemic, or other species of special concern (Clover and Jotter, 1944; Polhemus and Polhemus, 1987).

Previous geologic maps provide descriptions of the geology and structure in the monument boundaries and surrounding area (Fisher, 1961; Bohannon and others, 1993; Beard, 1996; Billingsley and Workman, 2000; Billingsley and others, 2004; Billingsley and Wellmeyer, 2003; Felger and Beard, 2010; Langenheim and others, 2010).

\section{Acknowledgments}

I thank Gary Karst of the NPS and Kathleen Harcksen of BLM for their help and guidance in visiting Tassi and Pakoon Springs, for their assistance in developing an understanding of the landscape, and for their interest in guiding the preservation, restoration, and understanding of the hydrogeology of these springs.

\section{Hydrogeology}

The hydrogeologic system that supports spring flow to Tassi and Pakoon Springs consists of complex lithologic and structural controls. The relation between groundwater discharge from Tassi and Pakoon Springs and groundwater movement within the Grand Wash Trough is poorly understood. Tassi Spring comprises several springs and seeps discharging along the west side of the Wheeler Fault alongside Pigeon Wash. Discharge from Tassi Spring was estimated to be 25 gallons per minute (gpm) in 1980. Pakoon Springs, which discharges from late Tertiary sedimentary rocks, is the largest spring in Grand Canyon-Parashant National Monument. Discharge from Pakoon Springs was estimated at $130 \mathrm{gpm}$ in 1976.

Groundwater-level data for wells and springs measured in 1976 and 1997 that were retrieved from the USGS GWSI database (table 1) indicate that: (1) groundwater may be moving from north to south in the alluvium and sedimentary deposits within the Grand Wash Trough (fig. 3); (2) groundwater may be moving from east to west from Paleozoic rocks of the Grand Wash Cliffs into sedimentary rocks of the Grand Wash Trough (fig. 3); and (or) (3) groundwater may be moving from the northwest in Mesoproterozoic crystalline rocks of the Virgin Mountains into the northern part of the Grand Wash Trough. Regional groundwater recharge to the Grand Wash Trough may occur on the Grand Wash Cliffs and (or) the Virgin Mountains. Surface-water flows in washes in the Grand Wash Trough are ephemeral and occur only during larger runoff events.

\section{Geochemistry}

A subset of water-chemical data obtained by the Grand Canyon Wildlands Council Inc. (2002) provides an initial characterization of the groundwater discharging from springs within the Grand Canyon-Parashant National Monument boundary (table 2). Water chemistry parameters that were analyzed included selected major ions (calcium, magnesium, sodium, chloride, sulfate, and bicarbonate) and stable isotopes of (oxygen-18 $\left[{ }^{18} \mathrm{O}\right]$ and deuterium $\left[{ }^{2} \mathrm{H}\right]$ ).

The variations in water chemistry and specific conductance measured from spring discharge (Grand Canyon Wildlands Council Inc., 2002) primarily reflect the rock types through which the water is moving (fig. 4). Tassi and Pakoon Springs are similar in water chemistry to many other springs in 


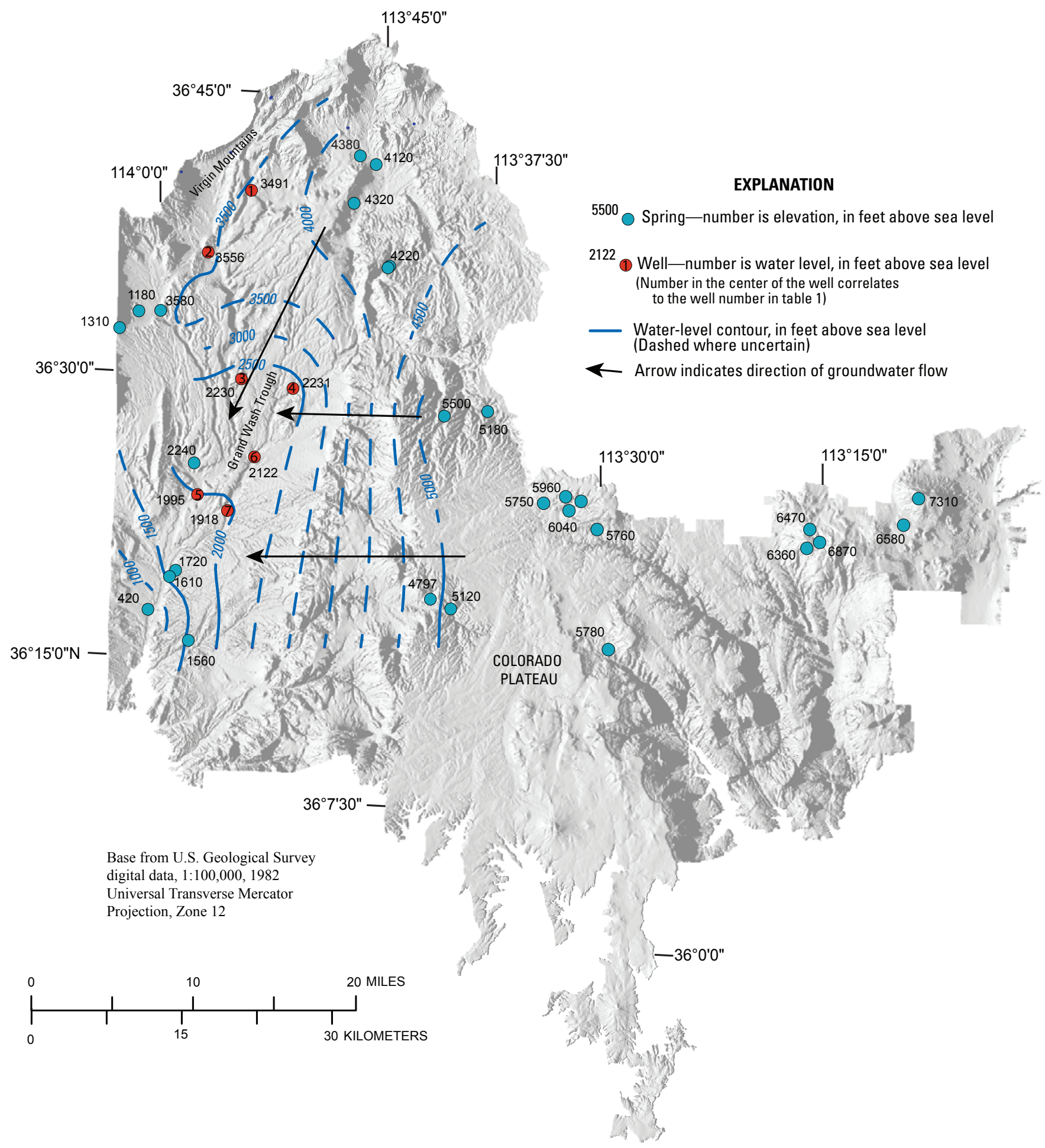

Figure 3. Water-level contours, springs, and wells in Grand Canyon-Parashant National Monument, northwestern Arizona. 
Table 1. Water levels and aquifer geology in wells in the western part of Grand Caynon-Parashant National Mounment, northwestern Arizona.

[Data from U.S. Geological Survey Groundwater Site Inventory]

\begin{tabular}{ccccccl}
\hline $\begin{array}{l}\text { Well number } \\
\text { (from fig. 3) }\end{array}$ & Station name & $\begin{array}{c}\text { Elevation } \\
\text { of land } \\
\text { surface } \\
\text { (feet) }\end{array}$ & $\begin{array}{c}\text { Water level, } \\
\text { below land } \\
\text { surface } \\
\text { (feet) }\end{array}$ & $\begin{array}{c}\text { Water level, } \\
\text { elevation } \\
\text { above sea level } \\
\text { (feet) }\end{array}$ & Date of measurement & Aquifer geology \\
\hline 1 & (B-38-15) 27CCA & 4,250 & 759 & 3,491 & $10 / 29 / 1991$ & Unconsolidated sedimentary deposits \\
2 & (B-37-15) 18DBC & 3,562 & 6 & 3,556 & $10 / 15 / 1997$ & Unconsolidated sedimentary deposits \\
3 & (B-36-15) 28BDD & 2,880 & 650 & 2,230 & $9 / 22 / 1976$ & Unconsolidated sedimentary deposits \\
4 & (B-36-15) 25DCD & 2,739 & 508 & 2,231 & $1 / 15 / 1997$ & Basalt \\
5 & (B-35-16) 36DAD & 2,000 & 5 & 1,995 & $9 / 22 / 1976$ & Unconsolidated sedimentary deposits \\
6 & (B-35-15) 22BAD & 2,340 & 218 & 2,122 & $9 / 21 / 1976$ & Basalt \\
7 & (B-34-15) 05DAB & 2,044 & 126 & 1,918 & $9 / 21 / 1976$ & Basalt \\
\hline
\end{tabular}

the western part of Grand Canyon-Parashant National Monument, characterized by low dissolved solids $(<500$ milligrams per liter (mg/L); fig. 4). However, both Spring 106 and Cove Springs in the western part of the monument have a high content of total dissolved solids $(>2,500 \mathrm{mg} / \mathrm{L})$ with elevated concentrations of sulfate $\left(\mathrm{SO}_{4}{ }^{2-}\right)$ and calcium $\left(\mathrm{Ca}^{2+}\right)$, suggesting the presence of gypsum $\left(\mathrm{CaSO}_{4} \cdot 2 \mathrm{H}_{2} \mathrm{O}\right)$ and (or) anhydrite $\left(\mathrm{CaSO}_{4}\right)$ along the groundwater flowpath. The water from Burro Spring has the highest content of total dissolved solids in the study area $(6,677 \mathrm{mg} / \mathrm{L})$, with elevated concentrations of sodium $\left(\mathrm{Na}^{+}\right)$, chloride $\left(\mathrm{Cl}^{-}\right)$, and $\mathrm{SO}_{4}^{2-}$, suggesting the presence of halite $(\mathrm{NaCl})$. The chemistry of Burro Spring differs significantly from that of Tassi, Buckhorn, and Whiskey Springs, all of which are relatively close to Burro Spring (fig. 4).

Stable-isotopic data (Grand Canyon Wildlands Council Inc., 2002) indicate that Tassi and Pakoon Springs have a more depleted isotopic signature relative to that of other springs on the Arizona Strip, including those in Grand Canyon-Parashant National Monument (fig. 5A). Isotopic signatures for springs in the monument generally indicate that springs located in the western part of the monument may have different recharge regimes from those in the eastern part (fig. $5 B$; table 2).

Tassi and Pakoon Springs have a more depleted stableisotopic signature and elevated temperture relative to other springs in Grand Canyon-Parashant National Monument. Several environmental conditions that could result in these signatures include (1) deep-circulating groundwater flowpaths; (2) a mixture of older and younger groundwater, suggesting multiple recharge sources and groundwater flowpaths; (3) seasonal variations from winter and summer storms; and (or) (4) a higher recharge elevation. Tassi Spring discharges from multiple seeps along the Wheeler Fault, and its depleted isotopic signature suggests that water may be flowing from multiple places into Lake Mead that seem to have a higher elevation or an older climate source. Elevated water temperatures and a depleted stable-isotopic signature for Pakoon Springs suggest that the water may be traveling along a deep-circulating flowpath, have multiple sources, has been recharged at a high elevation, and (or) has an older climate source.

\section{Summary}

Available hydrologic and water-chemical data are sparse for the western part Grand Canyon-Parashant National Monument near Tassi and Pakoon Springs in the Grand Wash Trough. Groundwater movement in and recharge to the Grand Wash Trough is poorly understood. Existing groundwater-level data indicate that groundwater may be moving from north to south in the Grand Wash Trough and receiving recharge from the Grand Wash Cliffs and the Virgin Mountains to the east and northwest, respectively. Water-chemical data indicate that many of the springs, including Tassi and Pakoon Springs, have a low content of total dissolved solids, and only a few springs have higher content of total dissolved solids. Tassi and Pakoon Springs have depleted ${ }^{18} \mathrm{O}$ and ${ }^{2} \mathrm{H}$ stable-isotopic signatures relative to springs on the Arizona Strip or within the monument. Stable-isotopic signatures for Tassi and Pakoon Springs may result from (1) deep-circulating groundwater flowpaths; (2) a mixture of older and younger groundwater suggesting multiple recharge sources and groundwater flow paths; (3) seasonal variations from winter and summer storms; and (or) (4) a higher recharge elevation.

\section{Future Studies}

Previous studies did not focus on constructing a conceptual hydrogeologic-framework model to better understand the relation of the geologic structure, lithology, and groundwater movement between Grand CanyonParashant National Monument and the towns of Mesquite, Nev., and St. George, Utah. Historical water-level data from the few existing wells in the monument provided 
Table 2. Major-ion and stable-isotope chemistry from springs in the western part of Grand Canyon-Parashant National Monument, northwestern Arizona.

[All data collected by the Grand Caynon Wildlands Council Inc. (2002); mg/L, milligram per liter; per mil, parts per thousand; --, no data; latitude and longitude in degrees-minutes-seconds]

\begin{tabular}{|c|c|c|c|c|c|c|c|c|c|c|c|c|c|}
\hline Site & Latitude & Longitude & $\begin{array}{c}\text { Calcium } \\
\mathrm{mg} / \mathrm{L} \\
\end{array}$ & $\begin{array}{c}\text { Magnesium } \\
\mathrm{mg} / \mathrm{L}\end{array}$ & $\begin{array}{c}\text { Sodium } \\
\mathrm{mg} / \mathrm{L}\end{array}$ & $\begin{array}{c}\text { Potassium } \\
\mathrm{mg} / \mathrm{L}\end{array}$ & $\begin{array}{c}\text { Chloride } \\
\mathrm{mg} / \mathrm{L} \\
\end{array}$ & $\begin{array}{c}\text { Sulfate } \\
\mathrm{mg} / \mathrm{L}\end{array}$ & $\begin{array}{c}\text { Bicarbonate } \\
\mathrm{mg} / \mathrm{L}\end{array}$ & $\begin{array}{c}\text { Alkalinity, } \\
\text { as } \mathrm{CaCO}_{3} \\
\mathrm{mg} / \mathrm{L} \\
\end{array}$ & $\begin{array}{c}\text { Dissolved } \\
\text { solids } \\
\mathrm{mg} / \mathrm{L} \\
\end{array}$ & $\begin{array}{c}\text { Delta Oxygen-18 } \\
\left(\delta^{18} 0\right) \\
\text { per mil }\end{array}$ & $\begin{array}{c}\text { Delta Hydrogen-2 } \\
\left(\delta^{2} \mathrm{H}\right) \\
\text { per mil } \\
\end{array}$ \\
\hline Buckhorn Spring & 361909 & 1135828 & 77.0 & 37.0 & 20.7 & 7.1 & 91 & 106 & 255 & 209 & 464 & -11.83 & -93.6 \\
\hline Burro Spring & 361700 & 1140015 & 399 & 130 & 1655 & 10.5 & 2,254 & 2,147 & 166 & 136 & 6,677 & -8.17 & -65.9 \\
\hline Cane Spring & 363912 & 1134709 & 36.3 & 10.0 & 7.2 & 1.5 & 3 & 10 & 168 & 138 & 151 & -13.16 & -97.0 \\
\hline Cove Spring & 363259 & 1140000 & 386.0 & 164.0 & 143.0 & 1.6 & 158 & 1,618 & 180 & 148 & 2,559 & -10.36 & -79.7 \\
\hline Hidden Spring & 362812 & 1133744 & 58.2 & 19.9 & 9.3 & 1.3 & 28 & 67 & 169 & 139 & 267 & -11.82 & -91.0 \\
\hline Lower Pigeon Spring & 361800 & 1134115 & 44.1 & 33.7 & 13.2 & 2.3 & 49 & 12 & 246 & 202 & 276 & -12.48 & -90.4 \\
\hline Middle Spring & 363207 & 1140245 & 43.4 & 35.3 & 4.5 & 0.7 & 5 & 9 & 291 & 239 & 241 & -12.11 & -89.48 \\
\hline Mud Spring & 364146 & 1134649 & 43.9 & 16.1 & 17.5 & 1.7 & 24 & 19 & 166 & 136 & 203 & -11.29 & -85.8 \\
\hline Pakoon Springs & 362458 & 1135726 & 99.2 & 19.0 & 18.0 & 13.0 & 57 & 50 & 185 & 152 & 348 & -13.51 & -102.9 \\
\hline Rattlesnake Spring & 362753 & 1134039 & 54.1 & 14.2 & 13.8 & 0.8 & 19 & 28 & 194 & 159 & 224 & -11.77 & -89.8 \\
\hline Red Rock Spring & 363304 & 1140129 & 87.2 & 34.0 & 20.0 & 1.7 & 25 & 6 & 421 & 345 & 380 & -- & -- \\
\hline Spring 106 & 364120 & 1134444 & 492.0 & 268.0 & 217.0 & 6.1 & 182 & 2,315 & 230 & 189 & 3,592 & -9.21 & -77.7 \\
\hline Tassi Spring & 361524 & 1135729 & 45.7 & 28.0 & 25.2 & 2.6 & 27 & 84 & 169 & 139 & 296 & -12.56 & -97.7 \\
\hline Upper Jump north & 363552 & 1134437 & 84.8 & 26.0 & 8.0 & 0.8 & 18 & 221 & 146 & 120 & 431 & -11.66 & -87.8 \\
\hline Upper Jump south & 363546 & 1134443 & 62.8 & 22.4 & 7.2 & 0.9 & 13 & 111 & 154 & 126 & 293 & -12.41 & -87.4 \\
\hline Upper Pigeon Spring & 361733 & 1133951 & 52.3 & 25.0 & 25.7 & 1.2 & 98 & 17 & 243 & 199 & 339 & -11.85 & -90.3 \\
\hline Lower Pigeon Spring & 361730 & 1133951 & 23.0 & 28.3 & 25.7 & 0.6 & 89.8 & 21.5 & 172 & 141 & 273 & -11.94 & -89.7 \\
\hline Whiskey Spring & 361848 & 1135852 & 50.6 & 26.5 & 17.0 & 2.1 & 8 & 88 & 190 & 156 & 286 & -12.45 & -95.3 \\
\hline
\end{tabular}


EXPLANATION

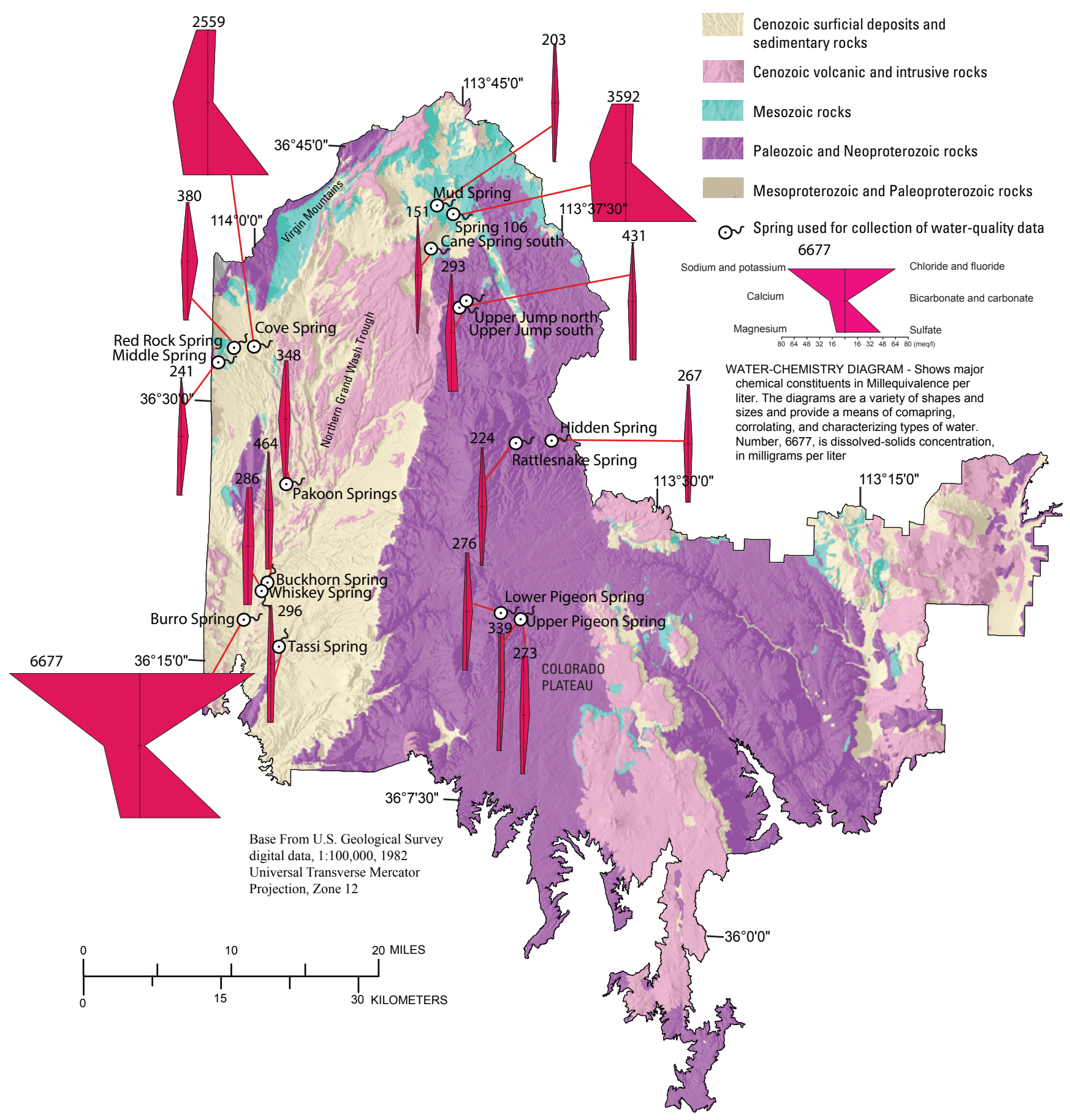

Figure 4. Grand Canyon-Parashant National Monument, northwestern Arizona, showing water chemistry and distribution of dissolved solids in the groundwater from springs. Data from the Grand Canyon Wildland Council, Inc. (2002). 

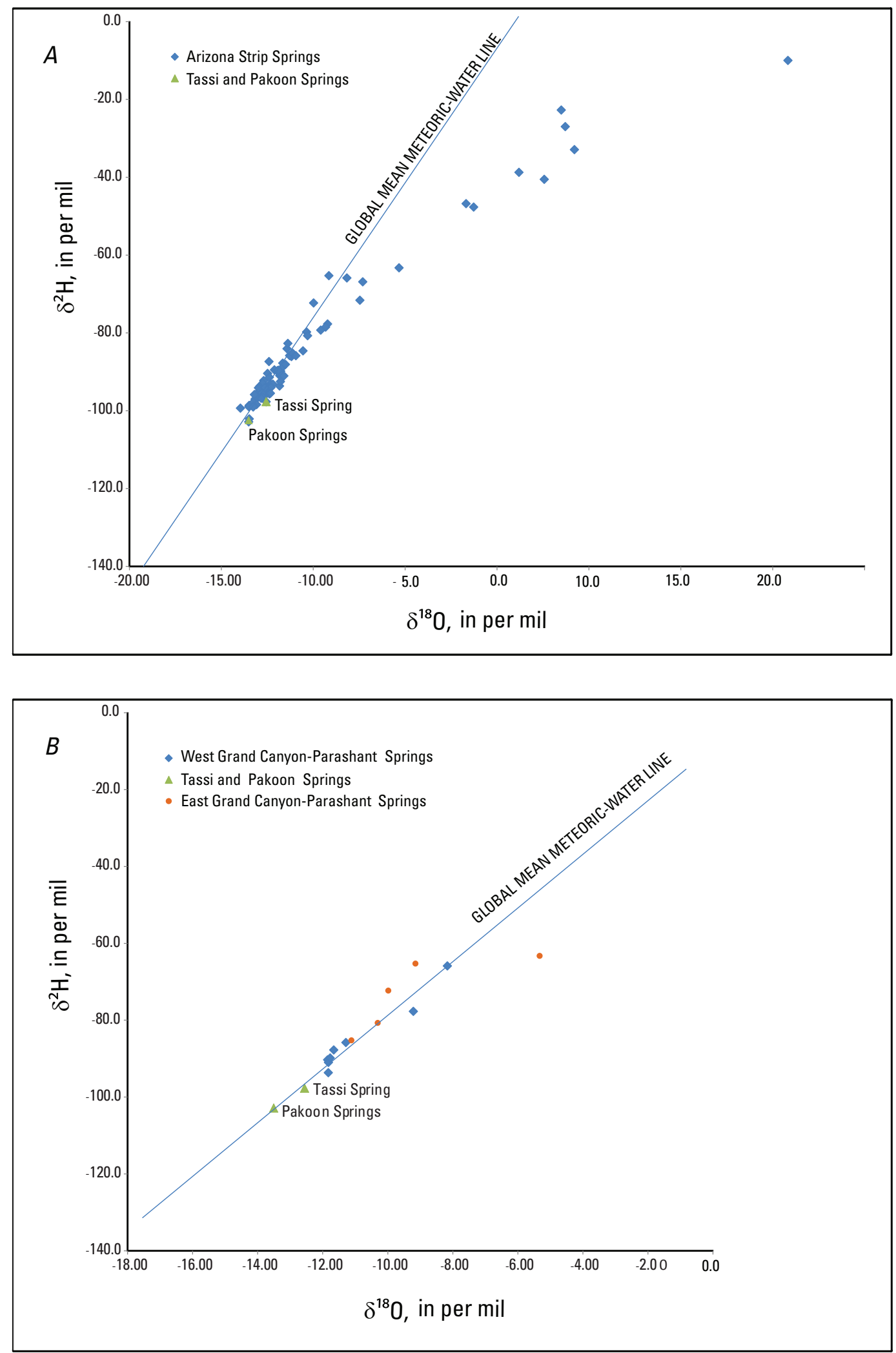

Figure 5. Signature of oxygen and hydrogen isotopes in water from selected springs in the Arizona Strip $(A)$ and in Grand Canyon-Parashant National Monument, northwestern Arizona (B). Stable isotopic data are from the Grand Canyon Wildlands Council, Inc., (2002). Units are given in parts per thousand (per mil). 
some indication of groundwater movement and direction but did not account for structural and lithologic controls. For example, does water move east to west from the Paleozoic rocks downward into the Grand Wash Trough, and what are the hydrogeologic units? How do the subbasins below the Grand Wash Trough (Langenheim and others, 2010) affect the movement of groundwater? Are the Virgin Mountains a barrier to groundwater movement between the towns of Mesquite, Nev., St. George, Utah, and the monument? The existing water-chemistry data were collected (Grand Canyon Wildlands Council Inc., 2002) with a primary focus on each individual spring and do not provide information about the regional connectedness of the springs to the local groundwater systems and hydrogeologic units. What are the groundwater flowpaths, and how old is the water discharging from the springs? Is there a mixture of old and young groundwater, suggesting local and nonlocal recharge? Where are the recharge sites for the regional groundwater system? What is the hydrologic connection between Tassi and Pakoon Springs and (or) other springs and the regional groundwater system? How old is the water from wells developed in Mesquite, Nev., and St. George, Utah, and does it have a similar recharge signature to water in the monument?

Answers to these questions can be addressed through studies that include remeasuring water levels from existing wells to compare the water levels measured in the late 1960s to mid-1970s and in the late 1990s, which could be used to discern any changes in the elevation of the groundwater table. Water-level measurements from wells developed in Mesquite,
Nev., and St. George, Utah, would provide additional information about groundwater movement and direction in relation to the faults and fractures through the Mesoproterozoic crystalline rocks of the Virgin Mountains.

Additional water-chemical sampling from Tassi and Pakoon Springs and selected springs and wells will include (1) resampling for major and minor ions and for stable isotopes $\left({ }^{18} \mathrm{O}\right.$ and ${ }^{2} \mathrm{H}$ ) to reduce the uncertainty in seasonal variations and the variation due to discharge points; (2) analysis of ${ }^{14} \mathrm{C}$ to date the older groundwater component; (3) analyses of chlorofluorocarbons (CFCs), noble gases, sulfur hexafluoride $\left(\mathrm{SF}_{6}\right)$, and tritium $\left({ }^{3} \mathrm{H}\right)$ to date the modern component of the groundwater; (4) analysis of groundwater and rocks for strontium- $87\left({ }^{87} \mathrm{Sr}\right)$, to provide geochemical signatures in order to discern groundwater flowpaths and identify the hydrogeologic units; (5) analysis for noble gases from selected springs and wells within Grand Canyon-Parashant National Monument and the cities of Mesquite, Nev., and St. George, Utah, to define recharge elevations; and (6) deployment of three to four sets of rain buckets from upper elevations down to lower elevations to collect rainwater in order to measure ${ }^{18} \mathrm{O}$ and ${ }^{2} \mathrm{H}$ to determine the most likely source elevation from the spring water.

Geophysical tools can be used to measure the resistivity of the rocks in order to characterize the structure and subsurface lithology, and to better understand local structural and lithologic controls near Tassi and Pakoon Springs. Geophysical tools can also be used to understand the subsurface structure and lithology of the rocks in areas where no other subsurface data exist. 


\section{References Cited}

Beard, L.S., 1996, Paleogeography of the Horse Springs Formation in relation to the Lake Mead Fault system, Virgin Mountains, Nevada and Arizona: Geological Society of America Special Paper 303, p. 27-60.

Billingsley, G.H., Beard, L.S., Priest, S.S., Wellmeyer, J.L., and Block, D.L., 2004, Geologic map of the Lower Grand Wash Cliffs and vicinity, Mohave County, northwestern Arizona: U.S. Geological Survey Miscellaneous Field Studies Map MF-2427, scale 1:31,680, 23 p. [http://pubs.usgs.gov/ mf/2004/2427/, accessed Dec. 6, 2012].

Billingsley, G.H., and Wellmeyer, J.L., 2003, (rev. 2006), Geologic map of the Mount Trumbell 30' x 60' quadrangle, Mohave and Coconino Counties, northwestern Arizona: U.S. Geological Survey Geologic Investigations Series I-2766, scale 1:100,00, 36 p. [http://pubs.usgs.gov/imap/ i2766/, accessed Dec. 6, 2012].

Billingsley, G.H., and Workman, J.B., 2000, Geologic map of the Littlefield $30^{\prime}$ x $60^{\prime}$ quadrangle, Mohave County, northwestern Arizona: U.S. Geological Survey Geologic Investigations Series Map I-2628, scale 1:100,000, 25 p. [http:// pubs.usgs.gov/imap/i2628/, accessed Dec. 6, 2012].

Bohannon, R.G., 1984, Nonmarine sedimentary rocks of Tertiary age in the Lake Mead region, southeastern Nevada and northwestern Arizona: U.S. Geological Survey Professional Paper 1259, $72 \mathrm{p}$.

Bohannon, R.G., Grow, J.A., Miller, J.J., and Blank, R.H., Jr., 1993, Seismic stratigraphy and tectonic development of Virgin River depression and associated basins, southeastern Nevada and northwestern Arizona: Geological Society of America Bulletin, v. 105, no. 4, p. 501-520.

Bureau of Land Management, 2012, Grand Canyon-Parashant National Monument, visitor information map [available at http://www.blm.gov/pgdata/etc/medialib/blm/az/images/ parashant.Par.15818.File.dat/parashantmap.pdf, accessed Jan. 16, 2012].
Clover, E.U. and L. Jotter, 1944, Floristic studies in the canyon of the Colorado and tributaries: American Midland Naturalist, v. 32, p. 591-642.

Felger, T.J., and Beard, L.S., 2010, Geologic map of Lake Mead and surrounding regions, southern Nevada, southwestern Utah, and northwestern Arizona: Geological Society of America Special Paper 463, p. 29-38.

Fisher, W.L., 1961, Upper Paleozoic and lower Mesozoic stratigraphy of Parashant and Andrus Canyons, Mohave County, northwestern Arizona: Lawrence, University of Kansas, Ph.D. dissertation, 345 p.

Grand Canyon Wildlands Council, Inc., 2002, Arizona Strip springs, seeps and natural ponds - an inventory, assessment, and development of recovery priorities, report for Arizona Water Protection Fund: Arizona Department of Water Resources, Grant 99-074WPF, 49 p.

Iorns, W.V., Hembree, C.H., and Oakland, G.L., 1965, Water resources of the Upper Colorado River basin - technical report: U.S. Geological Survey Professional Paper 441, 370 p.

Langenheim, V.E., Beard, L.S., and Faulds, J.E., 2010, Implications of geophysical analysis on basin geometry and fault offsets in the northern Colorado River extensional corridor and adjoining Lake Mead region, Nevada and Arizona, in Umhoefer, P.J., Beard, L.S., and Lamb, M.A., eds., Miocene tectonics of the Lake Mead region, central Basin and Range: Geological Society of America Special Paper 463 , p. 39-59.

Levings, G.W., and Farrar, C.D.,1979, Map showing groundwater conditions in the Virgin River, Grand Wash, and Shivwits Areas, Mohave County, Arizona-1976: U.S. Geological Survey Water Resource Investigations Open-File Report 79-57.

Polhemus, J.T, and Polhemus, D.A., 1987, Aquatic and semiaquatic Herteroptera of Grand Canyon (Insecta - Hemiptera): Great Basins Naturalist, v. 36 p. 221-226.

Western Regional Climate Center, 2012, Pipe Springs National Monument, Arizona, 1981-2010 temperature and precipitation [http://wrcc.dri.edu/cgibin/cliF302010.pl?az6616, accessed Dec. 10, 2012]. 
Menlo Park Publishing Service Center, California Manuscript approved for publication November 9, 2012 Edited by George Havach and Claire Landowski Layout and design by Judy Weathers 


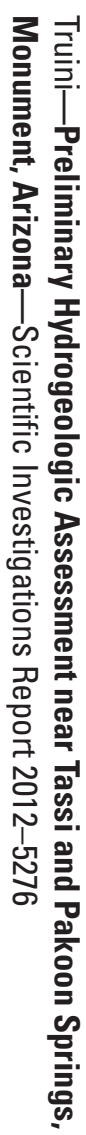

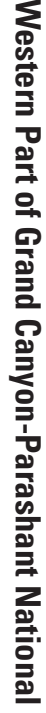

